Notes

\title{
The Affirmative Duty to Integrate in Higher Education
}

\section{Introduction}

In the sixteen years since Brown $v$. Board of Education, ${ }^{1}$ there has been an evolutionary expansion of the duty to desegregate state elementary and secondary school systems once segregated by law. Southern higher education, however, is today marked by racial separation and by a general inferiority of the historically Negro colleges. This Note will consider whether the Supreme Court's holding in Green v. School Board of New Kent County, Virginia ${ }^{2}$ has any implications for higher education. The specific questions to be answered are: (1) since there is still a racially identifiable dual system of public higher educational institutions in the South, do the states have a duty to take affirmative steps (beyond establishing racially nondiscriminatory admissions policies) to encourage integration; and (2) if such a duty exists, how do the current circumstances of higher education condition the scope of duty and the remedies which courts may enforce? The need for standards ${ }^{3}$ to measure a state's compliance with Brown in higher education is particularly acute because the Office of Civil Rights for the Department of Flealth, Education and Welfare has required several states ${ }^{4}$ to submit plans

1. 347 U.S. 483 (1954) [hereinafter cited as Brown 1]. The second Brown decision, on the question of relief, appears at 349 U.S. 294 (1955) [hereinafter cited as Brown II].

2. 391 U.S. 430 (1968) [hereinafter cited as Green].

3. The desegregation regulations for elementary and secondary cducation, 45 C.F.R. $\S \S 181.1-181.7$ (1968), promulgated by HEW under Title VI of the Givil Rights Act of 1964, 42 U.S.C. § 2000d, are extensive and detailed, but those applying specifically to higher cel* ucation are extremely brief and extend mainly to providing assurance of compliance with present and future HEW regulations attaching to any program in which the college or uni. versity participates, 45 G.F.R. $\$ 80(a)$ (1968). The only present regulation relating specifically to higher education prohibits racial discrimination in "admissions practices and . . all other practices relating to treatment of students," 45 C.F.R. $\$ 80.4$ (d)(1) (1968), Only four colleges have had federal funds terminated for refusing to submit assurances of cotn. pliance, and none have had funds terminated for discriminatory admissions practices. Leeson, Desegregation: Checking on Compliance, 3 SoutHERN ED. REP., April, 1968, at $37,38$.

4. In early 1969, HEW required such plans from Pennsylvania, Maryland, Mississippl, Louisiana, and Arkansas. N.Y. Times, March 11, 1969, at 22, col. 5. Sce generally, Pre'se sure on State Colleges to Integrate, U.S. NEws \& WORLD REPORT, March 31, 1969, at 32. 
showing how they will further integration in their colleges and universities, but HEW has given no criteria by which the plans will be judged."

\section{A. Evolution of the Affirmative Duly to Integrate in Elementary/Secondary Education}

The evolutionary expansion of the duty to desegregate in elementary/ secondary education is the product both of the Supreme Court's hazy initial definition of the requirements of Brown I and of active Southern resistance to desegregation in any form. In the Brown II decision on the question of relief, the Supreme Court emphasized the varied problems facing individual school districts and declined to propose a general standard by which compliance with Brown I could be measured. ${ }^{\circ}$ Instead, the Court remanded the four cases before it and directed that the lower courts guide themselves by "equitable principles" in fashioning ad hoc decrees which would ensure the admission of the plaintiffs to public schools "as soon as practicable on a nondiscriminatory basis."

Just a month and a half later, a serious ambiguity in Brown II became evident. The Supreme Court had declared that the plaintiffs were to be admitted to public school "on a racially nondiscriminatory basis with all deliberate speed."8 In Briggs $v$. Elliott, ${ }^{9}$ one of the three cases re-

5. In a March 3, 1969 letter to David Kurtzman, Pennsylvania State Superintendent of Public Instruction, Soloman Arbeiter, Higher Education Coordinator in HEW's Ofree of Civil Rights, noted that while Cheney State College had a student body that was 83\% Negro, Pennsylvania's other state colleges and Indiana University had a student enrollment that was approximately $99 \%$ white. The letter continued:

To fulfill the purposes and intent of the Civil Rights Act of 1964, it is not sufficient that an institution maintain a nondiscriminatory admissions policy if the student population continues to refiect the former racial identification of the institution. This appears to be the situation at all of the institutions revicwed and, therefore, these institutions must discharge their affirmative duty by adopting measures that will result in desegregation as soon as administratively possible.

A desegregation plan was required of the state within 120 days, but minimal standards by which the plan would be judged were not provided. Copy of letter on file at Yale Law Journal office. HEW seems uncertain what it can legally require of a state when racial isolation persists in higher education despite nondiscriminatory admissions policies, and this indecision is particularly acute with respect to the Negro colleges. Petcr Libarsi, former head of HEW's OCR has candidly admitted, "I don't know what to do about the Negro colleges ..... I don't think a Title VI enforcement program is the means of resolving basic policy issues." Leeson, Desegregation: Cheching on Compliance, 3 Sourriers ED. REP., April, 1968, at 37, 38.

6. The vagueness of the Brown II standards were widely criticized in the South and elsewhere. Shortly after the decision, the Richmond Times-Dispatch declared:

It would have been desirable if the court had ... specified the abolition of segregation by stages or steps, with, say, 10 per cent eliminated the first jear after the decrees became effective, 40 per cent two years later, perhaps, and the remaining 50 per cent some years after that. In this way, all uncertainty as to the timing and method of the tremendous shift would have been eliminated at once.

Quoted in Muse, The South's Troubled Years, 4 SourHenN ED. REP., Junc, 1969, at 19.

7. 349 U.S. at 300 .

8. 349 U.S. at 301 .

9. 132 F. Supp. 776 (E.D.S.C. 1955). 
manded with Brown, a South Carolina district court interpreted the state's duty under Brown II as merely a passive one:

[The Supreme Court] has not decided that the states must mix persons of different races in the schools or must require them to attend schools or must deprive them of the right of choosing the schools they attend. What it has decided, and all that it has decided, is that a state may not deny to any person on account of race the right to attend any school that it maintains .... The Constitution, in other words, does not require integration. It merely forbids discrimination. It does not forbid such segregation as occurs as the result of voluntary action. ${ }^{10}$

This distinction between "integration" and "desegregation" was widely approved and followed. ${ }^{11}$

During the 1954-1968 period, the Supreme Court expressed frequent dissatisfaction with the dilatory nature of the implementation of desegregation under this and other standards, ${ }^{12}$ and through the 1960 's, the Court's opinions in cases involving elementary and secondary school desegregation grew shorter and more peremptory. In a 1964 case which stemmed from the Brown I litigation, the Court asserted that " $[t]$ he time for 'deliberate speed' has run out,"13 and a year later declared, "[d]elays in desegregating school systems are no longer tolerable." 14

Finally, in May, 1968, the Court gave what would seem to be its final clarification of the Brown II decision for elementary and secondary school systems. ${ }^{15}$ The Court held the freedom-of-choice plan of New Kent County, Virginia, unconstitutional because it was not effectively

10. 132 F. Supp. at 777.

11. See Avery v. Wichita Falls Independent School Dist., 241 F.2d 230 (5th Cir.), ccrt. denied, 353 U.S. 938 (1957); Kelley v. Bd. of Educ., 270 F.2d 209 (6th Cir.), cert. denicd, 361 U.S. 924 (1959); Stell v. Savannah-Chatham County Bd. of Educ., 333 F.2d 55 (5th Gir.), cert. denied, 379 U.S. 933 (1964).

In 1966, the Fifth Circuit declared this distinction invalid: "Expression in our catlier opinions distinguishing between integration and desegregation must yield to this affirmative duty [to establish a nomracial unitary school system] we now recognize." Utited States v. Jefferson County Bd. of Educ., $372 \mathrm{~F} .2 \mathrm{~d} 836$ (1966), aff d on rehearing with modifications, 380 F.2d 385, 389 (5th Cir.), cert. denied, 389 U.S. 840 (1967).

12. Reluctant federal enforcement was compounded with active Southern resistance which took the form of school closings, tuition grants to private schools, pupil placcment plans, pupil transfer privileges, freedom of choice plans, and repeal of compulsory atten: dance laws; this story has been well documented elsewhere. See A. Bickel, The Decade of School Desegregation, in POLITICS AND THE WARREN COURT 3.48 (1965); R. SARRATr, THi: ORDEAL OF DEsEgregation: THE First Decade (1966); R. Carter, The Warren Court and Desegregation, 67 Mich. L. REv. 237 (1968).

13. Griffin v. County School Bd., 377 U.S. 218, 234 (1964).

14. Bratley v. School Bd., 382 U.S. 103, 105 (1965).

15. The Court considered three companion cases: Green (ineffective frecdom-of-cholce plan); Raney v. Bd. of Educ., 391 U.S. 443 (1968) (ineffective frecdom-of-choice plau); Monroe v. Bd. of Commr's, 391 U.S. 450 (1968) (ineffective free transfer plan). 
abolishing the dual system: ${ }^{16}$ the two county public schools were still identifiably white and black. ${ }^{17}$ In tracing the history of the Brown decisions, the Court emphasized that the goal of a racially nondiscriminatory school system did not simply mean a system where black children courageous enough to break with tradition were afforded a place in a white school. ${ }^{18}$ Instead, the goal was complete integration, achievement of a "unitary, nonracial system of public education."10 In public elementary and secondary school systems, this was to be the only standard by which the state's fulfillment of its Equal Protection Clause duty not to discriminate on the basis of race would be measured. Actual racial mixing of school children was the true indication of complinnce with Brown, and if a desegregation plan was not achieving this result, the school board was under an affirmative duty to try some more effective method. ${ }^{3}$ Unlike the constitutionally more difficult problem of de facto segregation, the presently existing dual system of public education in the South is a direct product of state action; despite present admissions standards, the segregated enrollment pattern existing today has descended without interruption from previous de jure segregation.

\section{B. "Equality" in Higher Education under the} Separate-but-Equal Standard

Although the Brown cases involved elementary/secondary education, the Supreme Court had first begun giving real content to the "equal" part of the separate-but-equal doctrine ${ }^{21}$ in the field of higher education. Beginning in 1938, the pre-Brown cases on higher education show a gradual evolution of greater stringency in the requirements imposed upon the states as the Court reluctantly began to examine the quality

16. Green v. County School Bd., 391 U.S. 430, 441 (1965). The Court noted that the "first step" taken by the School Board, institution of the freedom-of-choice plan, did not occur until eleven jears after Brown I: "[T] tutional dual system can only have compounded the harm of such a system." 391 U.S. at 438.

17. In the three years of the freedom-of-choice plan's operation, not a single white child chose to attend the Negro school. Although 115 black children had enrolled in the white school in 1967, 85\% of the black children in the system still attended the all-Nigro school. "[T] he plan has operated simply to burden children and their parents with a responsibility which Brown II placed squarely on the School Board." 391 US. at 441 .

18. 391 U.S. at 435.

20. 391 U.S. at 437-38. See also Alexander v. Holmes County Bd. of Educ, - U.S. 90 S.Ct. 29 (1969).

21. This doctrine was announced in Plessy v. Ferguson, 163 US. 537 (1890), which upheld a Louisiana statute requiring the assignment of passengers on the basis of color to segregated railway carriages and applied to public schools in Cumming v. Bd. of Educ., 175 U.S. 528 (1899). In 1908, the Court upheld the conviction of Berea College for violation of a Kentucky statute which forbade interracial education by "any person, corporation, or association of persons." Berea College v. Kentucky, 211 U.S. 45 (1905). 
of the "equality" provided blacks in education."2 In the first of these cases, Missouri ex rel. Gaines v. Canada ${ }^{23}$ the Court held that a Missouri statute allowing the state to pay the tuition of black graduate students at graduate schools in adjacent states was an unconstitutional denial of those students' rights to equal educational facilities. Lloyd Gaines was held to have the personal right to a legal education within the state borders which was "substantially equal"24 to that provided by the state for its white students. ${ }^{25}$ In two later cases, however, the Court was forced to wrestle with more difficult questions about the meaning of "equality" under the Plessy standard. In Sweatt v. Painter, ${ }^{20}$ the Court held that petitioner had been denied his right to an "equal" education because the white University of Texas Law School was superior to the Negro Texas State University in terms of faculty, curriculum, library, and availability of law review and similar activities. More importantly, the Court continued, the University of Texas Law School possessed to a far greater degree "those qualities which are incapable of objective measurement but which make for greatness in a law school," such as reputation of faculty, experience of the administration, position and influence of the alumni, standing in the community, tradition, and prestige. ${ }^{2 \tau}$ In McLaurin $v$. Oklahoma State Regents, ${ }^{28}$ a black graduate

22. In education, the "equality" called for by the Plessy rule quickly became a casu. alty of separateness. See Cumming v. Bd. of Educ., 175 U.S. 528 (1899); Reynolds v. Bd. of Educ., 66 Kan. 672, 72 P. 274 (1903); Dameron v. Bayless, 14 Ariz. 180, 126 P. 273 (1912). See generally Annotation, Equivalence of educational facilitics extended by public school system to members of white and members of colored race, 103 A.L.R. 713 (1936), and Separate-but-Equal: $A$ Study of the Career of a Constitutional Concept, 1 RACr Rit. L. REP. 283 (1956). In reviewing the history of Tennessee's segregated system of public educa. tion, Judge Gray stated: "The races were certainly kept separate in the schools, but I would assume that no one would argue in good faith that the schools were cqual." Sanders v. Ellington, 288 F. Supp. 937, 939 (M.D. Tenn. 1968). For a description of Southern higher education under the separate-but-equal standard, see U.S. Commission on Civil Rights, Equal Protegtion of the Laws in Punlic Higher Enucation 2.48 (1060).

23. 305 U.S. 337 (1938).

24. 305 U.S. at 351 . There is a chilling aftermath to the Gaines case which illustrates the dangers faced by early litigants who challenged the separate-but-equal system. After the Supreme Court decision, the Missouri legislature appropriated $\$ 200,000$ to establish a special law school for Gaines at Lincoln University (Gaines' alma mater). Gaines chat. lenged the adequacy of the hastily assembled facilities before the state suprcinc colurt, and the court remanded the case to the circuit court for the taking of evidence, Statc ex rel. Gaines v. Canada, 344 Mo. 1238, 131 S.W.2d 217 (1939). When the time cane for Gaines to testify, however, his attorneys announced that he had disappeared and could not be located. To this day, his fate is unknown. See Bluford, The Lloyd Gaines Story, 22 J. ED. Sociozocy 242 (1958).

25. Similarly, the Court's decision in Sipuel v. Bd. of Regents, 332 U.S. 631 (1948), was grounded upon the fact that the state of Oklahoma was providing a law school for white students but none for Negroes. Citing Gaines, the Court held that mandamus would lie to compel the admission of a black applicant to the state's only law school.

26. 339 U.S. $629(1950)$.

27. 339 U.S. at 634 . The Court also noted that education at Texas State would not be substantially equal to education at Texas because Sweatt would be deprived of the oppor. tunity to meet over $85 \%$ of the future members of the Texas bar. Id. at 634. Sucalt was 
student admitted to a white graduate school of education sued to remove the segregated conditions under which he was forced to study. 20 The Gourt held such conditions unconstitutional because they handicapped McLaurin in his pursuit of effective graduate education by impairing his ability to study and to enter into discussions with his fellow students.

When the separate-but-equal doctrine was overruled by Brown I, the duty of a state to maintain a racially nondiscriminatory admissions policy was quickly extended to higher education. ${ }^{\circ 0}$ In fact, it was held that the "all deliberate speed" principle of Brown II did not apply to graduate $^{31}$ or undergraduate education ${ }^{32}$ since such decrees did not "present the problems of [decrees in] elementary and secondary education."33

\section{The Role of the Gourts in Higher Education: \\ I Am Gurious, Green}

The post-Brown state of integration in higher education is illustrated by two recent cases. In Alabama State Teachers Association $v$. Alabama Public School and College Authority, ${ }^{34}$ a black teachers organization sought to enjoin a $\$ 5,000,000$ bond sale for construction of a four year degree-granting branch of Auburn University in Montgomery, Alabama, alleging that the state's action was unconstitutional because it would perpetuate the dual system in higher education. The plaintiffs argued that since the state had historically maintained a dual system that was still in existence (though no longer supported by law), the precedents from elementary/secondary education cases imposed on the state an affirmative duty to dismantle this system by expanding predom-

followed in Mckissick v. Carmichael, 187 F.2d 949 (4th Cir. 1951), when the Fourth Circuit used a comparative analysis similar to the Supreme Court's and found the Negro North Carolina College Law School greatly inferior to the white University of North Carolina Law School in terms of curriculum, ability and reputation of faculty, accreditation, law review activities, library facilities, physical plant, and general educational advantages; it ordered Floyd McKissick admitted to the University of North Carolina Law School.

28. 399 U.S. 637 (1950).

29. McLaurin was required to sit apart at a designated desk adjoining the classroom, to sit at a specified desk on the library mezzanine, and to sit at a special table and eat at a different time from other students in the school cafeteria. 339 U.S. at 640. Such integrated isolation did not disappear with Brown I; James Afercdith was to say of his existence at the University of Mississippi in 1962-63: "I was the most segregated Negro in the world." Quoted in R. SARRatT, The Ordeal of Desegregation 132 (1966).

30. Frasier v. Bd. of Trustees of the University of North Carolina, 134 F. Supp. 589

(M.D. N.C.), affd, 350 U.S. 979 (1955); Lucy v. Adams, 350 U.S. 1 (1955).

31. Florida ex rel. Hawkins v. Bd. of Control of Florida, 350 U.S. 113 (1950).

32. Meredith v. Fair, 305 F.2d 343, 352 (5th Gir.), cert. denied, 371 US. 828 (1962).

33. Florida ex rel. Hawkins v. Bd. of Control of Florida, 350 US. 413 (1956).

34. 289 F. Supp. 784 (MD. Ala. 1968), aff'd per curiam, 393 US. 400 (1969) [hereinafter cited as ASTA]. 
inantly black Alabama State College in Montgomery instead of constructing another branch of a predominantly white institution. Noting that " $[t]$ his argument presents a case of first impression," Judge Johnson denied the relief requested, stating that he was "reluctant ... to go much beyond preventing discriminatory admissions" and that his court did not "agree that the scope of the duty should be extended as far in higher education as it has been in the elementary and secondary public schools area." 35 The court's language is imprecise because while ostensibly recognizing an "affirmative duty" to dismantle the dual system, it asserts that this duty can be satisfied by a non-discriminatory admissions policy. ${ }^{36}$

In Sanders $v$. Ellington, ${ }^{37}$ faculty members and students of predominantly black Tennessee A \& I University, located in Nashville, brought a class action to enjoin expansion of the University of Tennessee's Nashville Center because, they alleged, it would continue to be a predom. inantly white institution. Enrollment at Tennessee $A \& I$ was $99 \%$ black while the other state universities were $89 \%$ white. The United States intervened on the side of the plaintiffs and sought, additionally, to compel the state to present a plan which was designed to produce significant integration throughout Tennessee's public colleges and uni* versities. The defendants argued that the two institutions would be complementary, since the Center would offer evening courses in engineering, business administration, liberal arts, and education, while Tennessee A \& I would offer approximately the same courses during the daytime. Accepting the defendants' argument, the court found that expansion of the Nashville Center would not necessarily perpetuate the dual system and denied the injunction. However, the court specifically refused to base its holding on the $A S T A$ case. Green was cited for the proposition that the state did have an affirmative duty ${ }^{38}$ to dismantle the dual system of higher education which, the court found, still existed in Tennessee despite racially non-discriminatory admissions policies. The court recognized that such policies did not meet the state's affirmative duty: "Nothing has been shown in the record to indicate that any plan has been proposed, devised, or considered to lead to the desegrega-

35. 289 F. Supp. at 787 (emphasis in original).

36. $289 \mathrm{~F}$. Supp. at 789 . The equation of "affirmative duty" and "nondiscriminatory ad. missions policy" is incorrect and misleading. Maintenance of non-discriminatory policies was the original command of Brown I; the Green concept of aftirmative duty implies imposition of further requirements in order to achieve integration.

37. 288 F. Supp. 937 (M.D. Tenn. 1968).

38. The court noted, however, that the Supreme Court "has not attempted to fashion a comprehensive definition of what that duty requires." 288 F. Supp. at 942. 
tion of [Tennessee A \& I] except the naked fact of an open-door policy." ${ }^{9} 9$ The state was given a "substantial amount of time" to submit a plan showing how it would fulfill this duty.10

Since the Sanders case was decided, however, the Supreme Court has summarily affirmed the decision in the ASTA case.11 Justice Douglas interpreted this action as holding that a state has no affirmative duty to desegregate a dual system of higher education and dissented strongly. He saw the case as governed by Green and rejected as "amazing" the suggestion that different standards applied to higher education. 2 Because the majority did not issue an opinion, however, it is difficult to ascertain the grounds of its affirmance. It is possible that $A S T A$ did not adequately establish that construction of the white Auburn branch would perpetuate segregated attendance patterns or that an alternate construction project at black Alabama State would ensure integration.

\section{Problem}

\section{A. Segregation in Higher Education Today}

Sixteen years after Brown I, higher education in the South, like elementary and secondary education, still presents a bleak picture of racial separation. ${ }^{43}$ During 1967-68, the last school year for which a survey was taken, $74.0 \%{ }^{44}$ of the black students in public institutions of higher education in the seventeen states ${ }^{45}$ where segregation was

39. 288 F. Supp. at 942.

40. $288 \mathrm{~F}$. Supp. at 940 .

41. 393 U.S. 400 (1969).

42. 393 U.S. at 401 .

43. In June, 1969, the Office of Civil Rights (OCR) of the Deparument of Health. Education, and Welfare estimated that approximately $20.3 \%$ of Southern blad: children were attending elementary and secondary schools with enrollments that vere at least 50\%
white. Muse, The South's Troubled Years, 4 Soutriern ED. REP., June, 1969 at 17. For an extensive analysis of segregation, both de jure and de facto, in the nation's public clementary and secondary school system, see U.S. CoMmission ON Civit RIGHrs, RACIAL. IsolaTION IN THE PUBLIC SCHOOLS, vols. I and II (1967).

44. U.S. OFFICE FOR CrVIL RIGHT, SURVEY OF HIGHER EDUCATION 1967.68 (1967), quoted in Leeson, Desegregation: Checking on College Compliance, 3 SOUnIERN ED. REP., April, 1968 at 41 . In 1967-68, 1,180,694 whites and 126,939 blacks attended public colloges and universities in these states, so this $74.0 \%$ figure represents approximatcly 93,935 black students. Id. A comprehensive list of Negro colleges and universities in the United States appears in E. MCGRATH, THE PREDOMINANTIY NEGRo CoLleGES AND UNIVERSTTIES iN TraN:sIrToN 172-177 (1965) [hereinafter cited as MCGRATH]. Aocording to MicGrath, there are 49 public universities, colleges, and junior colleges founded for Negroes in the seventeen Southern and border states, one in Pennsylvania, and one in Ohio; in the United States, there are 74 such institutions which are private. Id.

45. These states were Alabama, Arkansas, Delaware, Florida, Georgia, Kentucky, Louisiana, Maryland, Mississippi, Missouri, North Carolina, Oklahoma, South Carolina, Tennessee, Texas, Virginia, and West Virginia. The District of Columbia also maintained a segregated system of public schools. U.S. Crvir RIGrTs Cosmission, Equal Protection of THE LAWS IN HIGHER EDUCATION xiii n.7 (1960). 
legally enforced in 1954 were in colleges and universities established by law for Negroes ${ }^{46}$ and still overwhelmingly black in enrollment. Even this statistic does not accurately portray the severity of racial isolation in the deep South. In Mississippi, the percentage of black public college students in Negro public colleges is $92.4 \%$, in Georgia $90.6 \%$, in Alabama $90.2 \%$, in Virginia $89.3 \%$, and in South Carolina $85.9 \% .{ }^{47} \mathrm{Re}$ verse integration has been almost imperceptible in the deep South; a 1969 survey of the twelve Negro land grant colleges in this area revealed that full time white undergraduates comprised $.3 \%$ of the undergraduate enrollment of these institutions. ${ }^{48}$ This survey concluded:

Desegregation in state universities-and in the rest of higher education-has been talked about, declared, implied, and assumed to be substantial for several years. On the basis of [present] data . . . it seems fair to conclude that desegregation in these institutions has, in fact, been largely token. ${ }^{49}$

The history behind these statistics indicates an even greater failure to abolish the dual system than has occurred in elementary/secondary education. It was in higher education that the judicial erosion of separate-but-equal began, ${ }^{50}$ and the Brown decisions themselves cited many of these cases. Neither Brown nor any of the cases that followed it specifically exempted higher education from the requirements imposed in lower education; both Brown and Green speak only of "public education." 51 Ironically, many courts have held that there is an even more urgent need to desegregate white institutions of higher education than white elementary/secondary schools because black students desiring admission are "of mature age" and "are about to engage in the serious business of adult life." 52 And, as previously noted, the "with all

46. Many of these institutions are still statutorily designed as "Negro" or "colored"; see TENN. COde ANN., tit. 49 \& 3205 (1966); LA. REv. STAT., tit. 17, \& 10 (1969).

47. For the remaining Southern states, the percentages are: North Carolina- $85.8 \%$; Louisiana-81.8\%; Arkansas-79.6\%; Tennessee-77.4\%; Texas-56.5\%; Florida-51.3\%。 Similar figures for the border states are: District of Columbia-94.3\%; Delaware-86.2\%; Maryland-65.8\%; Oklahoma-34.3\%; Kentucky-33.5\%; Missouri-0.0\%; West Virginia$0.0 \%$. Leeson, supra note 46 , at 40 .

48. Survey conducted jointly by the Southern Education Reporting Service and the National Association of State Universities and Land-grant Colleges, reportcd in J. Egerton, A Survey of State Universities: Almost All-White, 4 SoutneRN ED. REP., May, 1969 at 2 ff. The same survey revealed that less than $2 \%$ of the students in the nation's state colleges and universities were black. $I d$. at 5 .

49. The survey continued: "The conclusion that black Americans are grossly under. represented in higher education seems inescapable." Quoted in New York Times, May 18, 1969 , p. 1, col. 3.

50. See pp. 669-71 supra.

51. Brown I: "[I]n the field of public education, ... 'scparate but equal' has no place." 347 U.S. at 495 . Green: "The transition to a unitary non.racial system of public education was and is the ultimate end to be brought about." 391 U.S. at 434.

52. Frasier v. Bd. of Trustees of the Univ. of North Garolina, 184 F. Supp. 589, 592.98 (M.D.N.C. 1955), aff'd per curiam, 350 U.S. 979 (1956). 
deliberate speed" principle of Brown II has been held not to apply to higher education ${ }^{53}$ since the administrative problems of elementary/ secondary education are not present there. ${ }^{\text {.t }}$

\section{B. The Emperor's Clothes: Quality of Public Negro Colleges in the South}

Racial separation is exacerbated by the fact that the public Negro colleges and universities are, on the average, greatly inferior to their white counterparts. Riesman and Jencks concluded that these colleges were "by almost any standard . . . academic disaster areas." described the Negro colleges as characterized by inadequate operating budgets, high drop out rates, low student SAT scores, low faculty salaries, few faculty $\mathrm{PhD}$ 's, inadequate science facilities, and a paucity of adult extension programs. ${ }^{56}$ Riesman and Jencks added the subjective conclusion that such colleges were also marked by academic parochialism, student incuriosity, faculty incompetence, and general intellectual torpor. ${ }^{\circ i}$ The Coleman Report analyzed the public Negro colleges in terms of thirteen comparative factors; ${ }^{58}$ many inadequacies were noted, but the deficiencies of "compelling proportion" were the low faculty salaries and the frequent incapacity of these institutions to move their students through the normal progression to a college degree. ${ }^{59}$ There was even evidence that four years at a Negro college was harmful to the achievement of

53. Meredith v. Fair, 305 F2d 343, 352 (5th Gir.), cert. denied, 371 U.S. 828 (1962): " $\Lambda$ s a matter of law, the principle of 'deliberate speed' has no application at the college Ievel; time is of the essence."

54. Florida ex rel. Hawkins v. Bd. of Control of Florida, 350 U.S. 413 (1950).

55. D. RIEsman \& C. Jencks, ThE Acadearic Rerolution 433 (1968). Not surprisingly, when this evaluation first appeared in 37 HARv. ED. REv. 3 (1967), it produced a storm of controversy. See G. Wright, B. Mays, H. Gloster, and A. Dent, The American Negro Colleges: $A$ Reply to Riesman and Jencks, 37 HARv. ED. REv. 451 (1967). Two other recent studies have been slightly less critical of the Negro colleges, though they have concurred with most of Riesman and Jencks' conclusions. MICGrath, supra note 44, at 5; A. JAFFE, W. ADAMS \& S. MIEYERS, NEGRo HIGHER EDUCATION IN THE 1960's 122 el seq. (1968). Rics. man and Jencks have been most criticized for their tendency to: (1) lump all public and private Negro colleges together and then make generalizations which compare the "average Negro college" with the very best white institutions; and (2) ignore the importance of black students' search for a racial and cultural identity. See Brigss, Keep the Negro Colleges, 4 Soutrern ED. REP., March, 1969 at 41; Jacobson, Negro Student Edilors W'ant "Black" Institutions, Chronicle of Hianer Ed., June 10, 1968, at 3, col. 4.

56. RIESMAN \& JENCKS 422, 429, 432, 437, 47i.

57. RIESALAN \& JeNcks 431, 455. "[T] he great majority of Negro institutions stand near the end of the academic profession in terms of student aptitudes, faculty competence, and intellectual ferment." Id. at 428.

58. US. Office of Education, Equality of Educational Opfontuntry (1960) [hercinafter cited as ColEMran REPORT]. These thirteen factors were: student-faculty ratio, per cent of faculty with earned doctorates, per cent of students from within the state, faculty salary mean, expenditure per student, room cost, presence of a Phi Beta Kappa chapter, presence of American Association of University Professors chapter, tuition and fees, library resources, size of student body, freshman/senior ratio, and freshman/student body ratio. Id. at 368-369.

59. Id. at 417 . 
blacks as compared to that of whites who had spent an equivalent period at a white college; in the case of education majors, results of non-verbal reasoning tests, mathematics tests, science tests, and social studies tests indicated a widening gap between the races from the first to the final year of college. ${ }^{.0}$ In an intensive survey in 1967, the Southern Regional Education Board found that the public Negro colleges and universities as a group did not match their predominantly white counterparts in admissions standards, breadth and depth of curricula, quality of instruction, and preparation for employment. ${ }^{\text {o1 }}$ Graduates of these instittu* tions often find their degree "a hollow symbol," the SREB concluded. $0^{\text {ot }}$ The states' insistence on maintaining a "separate" system for blacks has been marked by a determination that this system not be "equal" to the white institutions of higher education.

\section{Psychological and Cultural Value of the Historically Negro Colleges}

In Brown I, the Supreme Court held that state-enforced racial separation in the public schools ensured black children an education inherently unequal to that received by white children. The Court also em. phasized that such segregation created in black children "a feeling of inferiority as to their status in the community that may affect their hearts and minds in a way unlikely ever to be undone."03 The problem of integration in higher education is complicated by the fact that it is increasingly apparent that the Negro colleges have an important part to play in erasing the stigma of inferiority ${ }^{64}$ which decades of legal segregation has produced in many black children.05 These colleges by necessity have filled the role of the Fordhams, Brandeises, and Notre Dames of other ethnic minorities; ${ }^{66}$ they have prevented the assimilative

60. Id. at $344-345$.

61. Southern Regional Educhtion Bo.srd, The Negro and Higher Eduastion in till: South (1967), quoted in Campbell, Negro Colleges Have a Job, 3 SoutrierN ED. REF, November, 1967 at 3.

62. Id. at 4 .

63. 347 U.S. 483,494 (1954).

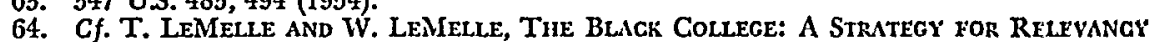
28 (1969): "We are only now beginning to admit the existence of a cheated black American society with special problems and distinct educational needs."

65. See Pettigrew, A Social Psychological View of the Predominately Negro College, 96 J. Negro Ev. 274 (1967), and Knoll, Colleges: The New Mlood of Blackness, SourintuN Ev. REP., July-August, 1968, at 17. Cf. E. ERICkson, Identity, Youtr, AND Grisis 42 (1968): "Desegregation, compensation, balance, reconciliation-do they not all sometimes sceit to save the Negro at the cost of an absorption which he is not sure will save mutch of himself?" Whitney Young, no separatist, has noted the value of the Negro colleges as "centers of cultural influence." W. Younc, To BE EQual 133 (1964).

66. Cf. RIESMAN \& JENCKs, supra note 55, at 452: "Like every minority group, Negroes need institutions they can call their own and in the American context a college is one of the most serviceable institutions a special interest group can have. . . It provides -. a platform from which ethnic leaders can speak with more legitimacy than most." 
death of Afro-American culture and have preserved "an identity beyond color that [is] cultural." of these colleges in creating "a positive sense of proud black identity [that is able to] erode the debilitating feelings of inferiority that have hamstrung the black American psychologically and thereby make ineffective the lingering anti-black feelings of racial bigots." be possible to apply the Green standard literally to higher education and to set up actual race mixing as the only test of compliance with Brown. However, the important psychological value of these colleges in correcting the cultural lobotomy of past second class citizenship ${ }^{53}$ would be demolished by instant racial homogenization. It would be a perverse misreading of Brown I to sacrifice, in the name of "equal educational opportunity," the most effective means of overcoming the stigma of racial discrimination..$^{70}$

\section{Value of the Historically Negro Colleges in Providing Remedial Education for Black Students}

Despite frequent academic inferiority to similar white institutions, the Negro colleges provide the only opportunity for many black students in the South to obtain higher education. This remedial function is a result of the relative poverty of many black students, the academic inferiority of many Negro high schools, and the racial separateness of Southern higher education. Abolition or rapid assimilation of the Negro colleges would probably abolish this function because such students would have to compete with whites from (on the average) superior high schools. ${ }^{71}$ Such an "equality" is Orwellian.

Experience demonstrates that when existing Negro institutions are dismantled, many black students are unable to gain admission elsewhere. For example, Florida abolished its Negro junior colleges between 1962 and 1965, and although special provision was made for

67. LENIELLE \& LEMIELLE, supra note 64 , at 34.

68. Id. at 132.

69. See Henderson, The Role of the Predominantly Negro Institutions, 36 J. Nearo ED. 266 (1967), and Campbell, Negro Colleges Hat'e a Job, 3 Soumiers Ed. REP., November, 1967 , at 3 .

70. The LeMfelle study concluded that of the "sereral means available to the black American community for achieving the positive black consciousness. . necessary for establishing relevant and effective black/white interdependence," black higher education provides the best "operational blueprint" because: (1) it is still largely controlled immediately by black Americans; (2) it has the largest and most available concentration of means for effectively politicizing the black community; (3) it has the most immediate access to the black youth whose task it will be to make this interdependency a reality. LEMELLE \& LEMEIIE, supra note 64, at 13-14.

71. None of the three recent studies of the Negro colleges has taken the view that they should be dismantled; all concur that many of them should be strengthened, while others should alter their scope by becoming junior colleges or by specializing in remedial educa- 
black students in the new system, there has since been a drastic decline in the number of black students enrolled in the consolidated junior college system. ${ }^{72}$ Evidence in the Sanders case indicated that if the white institutions in the Nashville area had set an entrance requirement of a score of 16 on the American College Testing Program (AGT) composite tests (the score supposedly indicating the minimum ability to perform acceptably in college), $78 \%$ of the Tennessee A \& I freshmen would not have been admitted. The mean score of the freshman classes at the historically white institutions ranged from 18.3 at Austin Peny State University to 22.0 at the University of Tennessee Nashville Center; the mean score at Negro Tennessee A \& I was $11.9^{73}$

Ironically, even the mediocre education provided at the public Negro colleges is a kind of subsidy for black students. Many black students benefit from the perpetuation of this system because they would be unable to qualify for admission under a color-blind admissions standard when whites were also competing for admission. Thus, McGrath has concluded that "the closing of the weaker institutions would deprive thousands of Negro youth of any opportunity for higher education."74 Also, these colleges have developed special skills in remedial education. Because they have been close to the problems of black students and have developed experience in dealing with these problems, they have established patterns that give them a great advantage, psychologically and organizationally, for the huge task of correcting the educational damage produced by inferior Negro high schools. ${ }^{75}$

tion, RIESMaN \& JENChs, supra note 55, at 452; JAFFE, ADAMS \& MEYERs, supra note 05, at 128; MCGRATh, supra note 44, at 159. "The view that many of the predominantly Negro colleges ought to be closed... springs from a false notion of academic excellence and. supports a policy in conflict not only with the rights of many disadvantaged youths, but also with the public interest. . . . Unless relatively inexpensive and local higher cduca. tion is available, hosts of potentially eligible Negro youth will be denied any educational opportunity beyond high school." MCGRATH at 160 .

72. Marsh, Junior Colleges and Negroes, 4 Southern Ed. REP., September, 1968, at 10. There has not been a significant increase in the number of blacks enrolled in faur'year colleges during this period either. $I d$.

73. 288 F. Supp. at 940.

74. McGrath, supra note 44 , at 8 .

75. F. Goldman, Educational Imperative: The Negro in the Changing Soum 2 (1969). For the present and potential value of these institutions in providing remcdial cducation for academically deprived Negro high school graduates, see MicGrat1, supra notc 41, at 53, and Wiggins, Dilemmas in Desegregation in Higher Education, $35 \mathrm{~J}$. NEGRO ED. 480 (1966). "[In the next decade, there will be] a shift in the conception of education from a status-giving and selective system that develops each individual to his highest potential. ... W] What is now required is not equality of access to education. . . but a system of compensatory education which can prevent or overcome earlier deficiencies in the develop. ment of each individual." K. BLoom, V. Davis \& R. Hess, Compensatory Education Fon Cultural Deprivation 285 (1965). 


\section{The Scope of the Duty in Higher Education}

The question of whether the state must do more than enforce racially non-discriminatory admissions policies involves the basic meaning of the Brown mandate. Brown may be interpreted to require only a nondiscriminatory admissions policy, to require instantaneous integration of all state colleges and universities, or to require that colleges comply with some set of intermediate standards that encourage integration but do not necessarily produce it immediately.

\section{A. The Requirement of Racially Non-discriminatory Admissions Policies}

In Green, the New Kent County School Board argued not that it was desegregating fast enough, but that it had desegregated completely because black students were provided a chance to attend white schools. Although the Supreme Court rejected this argument, Alabama and Tennessee also argued, in the $A S T A$ and Sanders cases, that they were complying with Brown because their colleges maintained racially nondiscriminatory admissions policies. However, it is clear that such policies are a mere genuflection to Brown and that many of the problems that triggered the Green decision exist in higher education also; the severity of racial isolation and the general inferiority of the Negro colleges have already been noted. ${ }^{76}$ The Southern colleges which are predominantly black today were founded by the states for Negroes only; ${ }^{7 \pi}$ although the laws enforcing segregation at these institutions were declared unconstitutional sixteen years ago, the state is as responsible in higher education as in elementary/secondary education for the attendance patterns originally established by de jure segregation which now condition student choice of institutions of higher education. ${ }^{78}$ The continued existence of such patterns indicates that de jure segregation has not been dis-

76. See pp. 673-76 supra.

77. See p. 674 supra.

78. The constitutional problem of finding state action in de faclo segregation is not presented in Southern higher education. The conventional definition of "de jure" and "de facto" segregation is stated in Taylor v. Bd. of Educ, 191 F. Supp. 181, 194 n.12 (S.D.N.Y.), affd, 294 F.2d 36 (2d Cir.), cert. denied, 368 U.S. 940 (1961): "[D]c jurc" should refer to segregation created or maintained by official act, regardless of its form. 'De facto' should be limited to segregation resulting from fortuitous residential patterns." Most courts have interpreted Brown I's "Separate educational facilities are inherenty unequal," 347 US. at 495 (1954), to apply only to instances where there has been a past history of de jure segregation or where there has been some affirmative diccriminatory action by the school board (such as racial gerrymandering or racial favoritism in allowing transfers). Bell v. School City of Gary, Indiana, 324 F.2d 209 (7th Cir.), cert. denied, 377 U.S. 924 (1964). 
established; the national commitment to extirpating such segregation, declared in Brown, is being dishonored and disobeyed.

The stringency of past judicial action to "desegregate" higher education has been noted.79 The fact that a stricter requirement than the "all deliberate speed" of the contemporaneous elementary/secondary education cases was enforced in the area of admissions in higher education seems to raise the inference that if affirmative action to encourage integration is required in elementary/secondary education, something more than racially non-discriminatory admissions policies will be required in higher education. Differences from elementary/secondary education, however, may affect the scope of this affirmative duty in higher education, continued application of the limited $A S T A$ rule of nondiscriminatory admissions policies will conjure once again the ghost of Briggs $v$. Elliott to walk abroad and turn the principles of the Fourteenth Amendment against their intended beneficiaries.

\section{B. The Requirement of Immediate Integration}

The Brown mandate for higher education might be interpreted as Green defined it for elementary/secondary education: the state is required to achieve immediately a unitary nonracial system of higher education. It would be possible to achieve almost instantaneous racial homogenization through some kind of centralized state admissions system to which students applied and from which they were assigned particular colleges. However, such a process would eliminate the cultural and non-academic differences among colleges which are the result of cumulative student choice of an institution because it represents certain values. By abolishing these fragile "qualities which are incapable of objective measurement," 80 such a system would extinguish the traditional values of the black colleges as curators of Afro-American culture; ${ }^{81}$ this would frustrate the wishes of many black students who wish to attend these colleges because they view them as a means of counteracting the lingering stigma of racial discrimination.

A centralized admissions system could either be strictly color-blind or it could include a quota system for educationally disadvantaged black students. In addition to obliterating the psychological/cultural functions of the Negro colleges noted above, these techniques would raise further problems.

79. See p. 671 supra.

80. Sweatt v. Painter, 339 U.S. 629, 634 (1950).

81. LEMELIE \& LEMELLE, suppra note 64 , at 35 compares them to the "isolated rnonase teries of the European Dark Ages." 
A state-wide color-blind admissions standard would put whites and blacks in direct competition and would thus destroy the remedial function of the Negro colleges. A class of "push-outs" would be created because many of the black students now in the Negro colleges would be rejected as academically unacceptable in a fully integrated and competitive system. ${ }^{82}$

A state-wide admissions system which attempted to achieve integration through some kind of a quota system would create the administrative difficulties of setting quotas, of determining how compensatory the standards would be as black high schools improved and became more integrated, and of adjusting the quotas as student preferences changed. Such a quota system would be handicapped by its inability to compulsorily assign students to specific academic programs; it would be possible to give a student the remedial education to become an engineer, but a student who wished to become an engineer could not be forced to become a teacher instead. Also, it has been suggested that such benevolent quotas may be unconstitutional; denial on the basis of race of an academically qualified white student's application to a state institution of higher education might violate the Equal Protection Clause. ${ }^{.3}$

The ASTA court felt that it could not utilize the techniques of geographical zoning, school pairing, and busing (all used in lower education) to integrate Alabama's state colleges, because the colleges were not evenly distributed geographically and were dissimilar in the academic functions they performed. Holding that Green applied directly to higher education, the court asserted, would have necessitated ordering a centralized admissions system which would abolish free student choice of institutions. For the administrative reasons described (but without considering the remedial and psychological/cultural values of the Negro colleges), the court declined to order such a plan. However, the assumption that requiring more of a state than non-discriminatory admissions necessarily means instituting some kind of a statewide student compulsory assignment plan is false. ${ }^{84} \mathrm{~A}$ set of "judicially

82. See pp. 677-78 supra.

83. See A. Bicker, THe Least Dangerous Branch 61-65 (1962). Bul sec Freund, Dedication-1964: Constitutional Dilemmas, 45 Boston U.L. REv. 13, 20 (1965).

84. Frequently, courts and commentators have erroneously equated imposition of an affirmative duty with abandonment of "freedom-of-choice" in higher cducition. Note, 82 HARv. L. REv. 1757 (1969), asserts: "Doctrinal considerations indeed may varrant a complete abandonment of the affirmative duty concept on the college level," id. at 1759, because "[e]ven if in principle ... one is willing to allow the imposition of an affurmative duty there may be valid educational considerations, as Judge Johnson pointed out in Alabama State Teachers, which argue for maintenance of the frce choice system." Id. at 1761. Judge Johnson rejected the applicability of Green to higher cducation because he apparently felt it would necessarily mean abandoning freedom-of-choice: "Freedom to 
discoverable ànd manageable" standards ${ }^{88}$ can be devised which requires the state to take a more active role in the integration of higher education but which leaves untouched the Pelagian virtues of the present system of student allocation. The ultimate goal is to eradicate the lingering effects of past de jure segregation which inhibit free student choice among institutions of higher education.

\section{Philosophy and Prescription}

\section{A. Proposed Standards: Assumptions, Operation, Results}

The following minimal standards are suggested to evaluate state efforts to desegregate higher educational institutions in the light of the Green decision. In state systems of higher education once racially segregated by law, student admissions policies must be free of racial discrimination; in addition, the state has the duty to:

(1) equalize per pupil expenditures on similar kinds of institutions insofar as such institutions are racially distinguishable;

(2) make positive efforts to alter present segregated attendance patterns by influencing student choice of colleges and universities through recruiting techniques;

(3) insure that the administrative staff and faculty of its institutions are desegregated;

(4) utilize expansions of facilities and new construction to gradually integrate the dual system.

These standards embody the assumption that integration of institutions of higher education is a desirable goal because discrimination on the basis of race is intolerable and because the present pattern of segregated enrollment at these institutions is a product of such discrimination. The standards are grounded on the belief that American society cannot be politically or socially stable if it is split into two

choose where one will attend college, unlike choosing one's elementary or secondary public school, has a long tradition and helps to perform an important function, viz. fitting the right school to the right student." $289 \mathrm{~F}$. Supp. at 790.

The NAACP Legal Defense Fund recognized this distinction, however, in its Jurisdlc. tional Statement on the appeal of the $A S T A$ case to the Supreme Court:

Since : . freedom-of-choice seems an appropriate system for higher cducation, doctrines such as the new construction doctrine, which can be used to make frecdomof-choice succeed in producing a unitary non-racial system, are of particular impor-a tance in the area of higher education.

Jurisdictional Statement for Appellants at 16 (emphasis in original).

85. Norwalk GORE v. Norwalk Redevelopment Agency, 395 F.2d 920, 929 (2d Cir. 1968). 
antagonistic and racially defined factions; ${ }^{\mathbf{S B}}$ it seems clear that racial harmony in higher education has a direct influence on the social and political cohesiveness of the larger society. ${ }^{37}$ The standards assume that unless the guarantees of the Constitution are to be rendered hollow hypocrisies, it will be necessary to take affirmative action to remedy the damage done by past state-sanctioned racial discrimination; this will entail both achieving greater integration and providing the kind of education that will best counteract the lingering effects of this discrimination. Finally, it is assumed that in order to enable courts to make decisions with predictability and consistency, it is desirable to devise standards which are as concrete and objectively ascertainable as possible and which allow compliance to be easily measured.

A more limited duty is imposed on the state in the area of higher education than Green imposed in elementary/secondary education; these standards represent, however, much broader requirements than courts have so far been willing to enforce. In order to preserve the psychological/cultural and remedial functions of the Negro colleges, the affirmative duty standard is defined here in terms of practices rather than results. Under Green, no practices needed to be prescribed because school boards were ordered to achieve a unitary nonracial system by whatever means necessary.

The practical effect of the two thrusts of the proposed standards (toward integration and toward improvement of the historically Negro colleges) will not be contradictory, although total commitment to either emphasis alone might subvert the other. Applying these standards, a court would view the goal of integration in higher education not as a system where colleges were totally indistinguishable by race but rather as one where there was substantial racial mixture in student enrollment at each institution and where there was approximate equality in terms of state appropriations, facilities, and faculty quality between what were once "white" and "Negro" institutions so as to make them both attractive alternatives for a student's choice of college. The proposed standards are necessarily tentative; if they do not bring about more integration than presently exists and if they do not effectively strengthen the Negro colleges, other standards should be imposed.

86. Cf. Hobson v. Hansen, 269 F. Supp. 401,508 (D.D.C. 1967), appcal dismissed, 393 U.S. 801 (1968): "Our common need [is] for the schools to serve as the public agency for neutralizing and normalizing race relations in this country."

87. In IIlinois ex rel. Mícollum v. Bd. of Educ, 333 U.S. 203, 216 (1947), Justice Frankfurter's concurrence declared that public schools were "the most porverful agency for promoting cohesion among a heterogeneous democratic people." 
In the short run, institutions will continue to be somewhat racially identifiable because the black institutions will remain committed to their own style of education and will have lower admissions standards as long as the Negro high schools are inferior to white high schools. But in the long run, enforcement of the standards will erode the stigma attached to the Negro institutions by decades of separate-butinferior status. ${ }^{88}$ White choice of black institutions will be affirmatively encouraged, and admission of black students to white colleges will be eased. The standards will also improve the quality of the black colleges. The goals of integration and Negro college improvement will be selfreinforcing: as more white students choose the Negro colleges, their quality will improve, and as their quality improves, more white students will be attracted.

\section{B. Equalization of Per Pupil Expenditure}

Despite rapidly growing aid from the federal government and private foundations, the state still provides the bulk of the operating capital for its institutions of higher education. ${ }^{80}$ Appropriations are objectively ascertainable and are controlled directly by the state in a way that other educational policies are not. In elementary/secondary school districts under freedom-of-choice plans, courts frequently used comparative per pupil expenditure by the local school board as an indication of whether black children were being provided an equal educational opportunity. ${ }^{.0}$

88. The Supreme Court's holding in Brown I that segregation in public cducation constitutes a denial of equal protection rests on two conclusions:

(1) such education denies Negro children a chance for an education equal to that of whites by its very nature; the Court analyzed Sweat and McLatrin and concluded that the logic of these cases applied "with added force to children in grade and high scliools," 347 U.S. at 493-494;

(2) such education causes psychological damage to Negro children by stignuatizing thent as inferior to white children: "To separate them from others of similar age and qualifications solely because of their race generates a fecling of inferiority as to their status in the community that may affect their hearts and minds in a way unlikely cver to be undone." 347 U.S. at 494.

These two conclusions are separate and distinct, but unfortunately, many later cases have equated and confused them. Increased white attendance of the Negro colleges is necessary to overcome the stigma attaching to these institutions, and this can probably only occur through affirmative recruiting efforts.

89. F. Heimberger, The State Universities, in R. Monuson (cd.), 'THE Contenronanx UNIVERSTrY: USA 62 (1966). See also Reeves, Higher Education and slate Tax Policy, 16 NAT. TAX J. 291 (1962).

90. In Hobson v. Hansen, 269 F. Supp. 401, 417 (D.D.C. 1967), appeal clismissed, 391 U.S. 417 (1968), the court found that the median annual per pupil expenditure (\$202) in predominantly (85-100\%) Negro schools in the District of Columbia had been a flat $\$ 100$ below the median annual per pupil expenditure in predominantly white schools (\$392) In the District. In United States v. Jefferson County Bd. of Educ., $372 \mathrm{~F} .2 \mathrm{~d} \mathrm{896,} 900$ (1966), aff'd on rehearing with modifications, 380 F.2d 385 (5th Cir.), cert. denied, 389 U.S. 840 (1967), Part VI of the Final Decree ordered, among other things, that "per pupil expenditures both as to operating and capital improvement costs" be equalized ainong the formerly Negro and white schools. 
In higher education, at a time when " $[t]$ he real key to the educational problems of the Negro colleges is money," 91 these colleges are receiving far less proportionately from the state than are their white counterparts, and they are spending per pupil about two-thirds what comparable white institutions are spending. ${ }^{92}$ In the U.S. Civil Rights Commission's 1960 study of integration in higher education, ${ }^{33}$ average per pupil expenditures were used to gauge the states' treatment of their white and black students, and gross disproportions were revealed. Louisiana, for example, had spent $\$ 1,123.57$ annually for each student enrolled in its seven traditionally white colleges as compared with $\$ 709.37$ for each student enrolled in its two Negro institutions; Florida had just spent $\$ 1,079.39$ per student at its historically white colleges and universities and $\$ 901.17$ per student at its historically Negro institutions. ${ }^{94}$ Over the past decade, the situation has improved somewhat, but in almost every state, the public Negro college still receives a harshly disproportionate share of the state's expenditures on higher education.95 The state should therefore be required to equalize per pupil expenditures at similar kinds of institutions insofar as such institutions are distinguishable by race..$^{96}$

While there is no constitutional requirement that a state equalize per student expenditures for its institutions of higher education, if there is a consistent pattern of discrimination against institutions that were legally established for Negroes only and that now have a predominantly black student enrollment, this discrimination violates the Equal Protection Clause because it is racial and not merely educational. ${ }^{97}$ After generations of de jure segregation, it "overlooks

91. Bayton, Reflections and Suggestions for Further Study Concerning the Higher Education of Negroes, 36 J. NeGro ED. 286 (1967). Cf. the conclusion of unc US. Civil Rights Commission: "No other single factor so directly affects the quality of culucition a college can offer as its available financial support." United States Commisston oN CiviL Rights, Equat Protection of the Laivs in Public Higher Education 103 (1980).

92. MCGrath, supra note 44, at 26. In the latest year for which comparable figures could be obtained, 1959-60, the average expenditure of the Negro college per student for educational and general purposes was $\$ 888$ compared with a national average of $\$ 1,334$. Id. The Coleman Report's chapter on higher education documents specific inequalities. HETW OfFice of Education, Equality OF EDUCATIONAL Opportunity 365-145 (1960).

93. US. Commission on Civil Rights, Equal Protection of thie Lail's in Hiciers. EDUCATION (1960).

94. Id. at 104,114 .

95. MCGRATH, supra note 44 , at 26.

96. This standard should not be applied to a state's bond issues (the usual way of financing new construction); the complexities of higher cducational planning make an exactly equal growth rate in the historically white and Negro systems both undesirable and impossible. The standards by which a court should review new construction are discussed below.

97. While it may take more money to train a physicist than a philosopher, the state should not be allowed to spend consistently less training its black physicists than it does training its white physicists. The duty to spend approximately equal amounts on pupils 
realities" 18 to say that the state is not responsible for these attendance patterns or to say that the state is now providing an opportunity for equal education because the doors of its white institutions are theoretically open. Choice is not really free for many black students; ${ }^{\text {jo }}$ they have been effectively "tracked" to inferior colleges because the state has provided them inferior high schools. ${ }^{100}$ Though the requirement of equal per pupil expenditure at similar institutions is reminiscent of the old pre-Brown separate-but-equal standard, such a requirement has repeatedly been enforced in elementary/secondary school systems operating under freedom-of-choice plans. ${ }^{101}$

It is clear that a state's overall per pupil expenditure for white and Negro colleges and universities will not be a useful figure for purposes of this requirement because so many different kinds of institutions are lumped together in the comparison. ${ }^{102}$ In elementary/secondary educit-

of different races has no necessary relation to the duty to integrate. See Coons, Cline, \& Sugarman, Educational Opportunity: $A$ Workable Constitutional Test for State Financial Structures, 57 CAL. L. REv. 305, 355.58 (1969), and more generally Horowitz, Unseparate but Unequal: the Emerging Fourteenth Amendment Issue in Public School Education, 18 U.C.L.A.L. REv. 1147 (1966).

98. Sweatt v. Painter, 339 U.S. 629, 634 (1950).

99. Of a freedom-of-choice plan at the elementary/secondary level, the Fourth Gircuit declared:

If there is a contention that economic or other pressures . . . inhibit the frec exercise of choice, there must be a judicial appraisal of [the contention] for "frcedom. of-choice" is acceptable only if the choice is free in the practical context of its exercise.

Bowman v. County School Bd., 382 F.2d 326, 327 (4th Cir. 1967).

100. For a study of the correlation of low SAT scores and predominantly Negro Southern high schools, see Deutsch and Brown, Social Influences in Negro.IWhite In. telligence Differences, $20 \mathrm{~J}$. Social Issues 24 (1964).

101. Part IV of the Decree entered in Lee v. Macon County Board of Education, 207 F. Supp. 458, 489 (M.D. Ala.), aff'd sub nom. Wallace v. United States, 389 U.S. 215 (1967) ordered the School Board to equalize the formerly all Negro schools with the white schools in terms of "per pupil expenditures both as to operating and capital improvement costs," and a similar order was entered in Coppedge v. Franklin County Board of Education, 279 F. Supp. 289, 301 (E.D.N.C. 1967). Part IV of the Order entered in United States v. Jefferson County Bd. of Education, 372 F.2d 836,900 , aff'd on rehearing with modifications, 380 F.2d 385 (5th Cir. 1966), cert. denied, 389 U.S. 840 (1967), ordered equalization of per pupil expenditures at white and black schools and also required the closing of black schools if it was not feasible to improve and equalize them as the Order required.

102. A state may abolish any or all of its public colleges and universities, but if it abolished only its Negro colleges without making provision for the students attending these colleges to go elsewhere, such action might violate the Equal Protection Clituse on either of two grounds: (1) because enrollment at such colleges is largely black, such action by the state demonstrates a racially discriminatory intent to deprive blacks of their opportunity for an education; or (2) because application of an ostensibly non-racilal uniform state-rvide admissions policy at all state institutions would constitute an actual discrimination against blacks (because of the inferior Negro high schools), the effect of thic state's action would be racially discriminatory. A state may not set up cducational requirements for admission to its institutions if the state's earlicr action has made it impossible for a certain class of applicants to meet these requirements. Dove v. Parham, 282 F.2d 256, 258 (8th Cir. 1960). In Franklin v. Parker, 223 F. Supp. 724 (M.D. Ala. 1969), modified, 331 F.2d 841 (5th Cir. 1964), the Dean of an Auburn University graduate scliool was enjoined from discriminating against graduates of a non-accredited state Negro college 
tion, the Negro and white schools were theoretically similar (in curricula, operating expenses, etc.), so a court could confidently assume that inequalities in per pupil expenditure in the same school district reflected discriminatory treatment. In higher education, comparison is also the key to justiciability, but the comparison must be refined so that a public Negro college is compared with a public white college of an approximately similar nature..$^{103}$

In some respects, it is far easier for a court to review a state's expenditures for higher education than those for elementary/secondary education, because in the former case there are fewer institutions, the tax base is the entire state, ${ }^{104}$ and appropriations are centralized. Also, in the past decade most states have set up centralized planning agencies

because the state was held to be responsible for its colleges' non-accreditation. In Hunt v. Arnold, 172 F. Supp. 847 (ND. Ga. 1959), a requirement that applicants to the Georgia State College of Business Administration submit a certification of good moral character from two alumni of the institution was held to be a denial of equal protection because all of the alumni were white (a result of state enforced segregation).

103. Because of the history and development of the public Negro colleges in the South, this comparison is not as difficult as it would perhaps seem. Under the separate-but-cqual theory, public Negro colleges were founded as reflections of white counterparts. H. Burtoch, A History of Negro Education IN THE SOUTH 138 (1967). The public Negro colleges "fell into the same categories as their white counterparts but the adjective "Negro" was heavily charged with lower standards." Id. at 184. These public Negro institutions are of basically three types: land grant colleges, junior colleges, and tcacher training colleges. In Southern states, there are usually two land grant universities, and these have basically similar course offerings; usually, one is the state university (white) and one is an A \& M or A \& I university (Negro). Junior colleges are another distinctive type of institution; here, a comparison of per pupil expenditures at Negro and white junior colleges will be an accurate indication of whether a state is providing racially cqual treatment because curricular differences among these institutions are minimal. Sec Marsh, Junior Colleges and Negroes, 4 SourherN ED. REP., Sept., 1968 at 10; sec generally JAFFEE, ADAMS \& MEYERS, supra note 55, at 98-117. It is somewhat more diffeult to find white equivalents for the Negro colleges set up to provide teacher training and a liberal arts curriculum; however, the standards of comparison for each such Negro college should be the public white college whose total curriculum is most similar to that of the Negro college.

Appendix G of U.S. Crvic Rights Commission, Equal Protecrion of tite Laws IN HigreR EDUCATION (1960) demonstrates the feasibility of such comparisons; here, the white and Negro public institutions of each state are analyzed and compared in terms of curriculum offered, highest level of offering, and special programs offered. As an example of how the suggested standard could be applied, the following per pupil expenditures comparison could be made for Mlississippi:

(1) land grant Alcorn A \& M (Negro)-land grant Mississippi State College (white);

(2) the average per pupil expenditures at the state's fourteen white junior colleges

with that at the state's four Negro junior colleges; (3) Delta State College (whitc)-

Jackson State College (Negro). Id. at Appendix G, table 5.

104. For this reason, a case involving appropriations for higher education should be distinguished from McInnis et al. v. Ogilvie, 293 F. Supp. 327 (N.D. Ill. 1968), af'd, 394 U.S. 322 (1969). In this case, a three-judge court for the Northern Distriet of Illinois held that the state had no constitutional duty to equalize per pupil expenditures among its school districts. The constitutionality of financing elementary/secondary education by local property taxes was thus upheld even though some school districts would receive proportionately less money than others because their total property valuation was proportionately Iower. Such a rationale would clearly not apply here because appropriations for higher education come from taxes that are levicd on a state-ivide basis. 
for higher education to supervise requests for appropriations, coordinate the state's graduate and professional programs, and plan the expansion of the state's public colleges and universities..$^{105}$

Equalizing per pupil expenditures at similar kinds of institutions will certainly not solve all of the financial problems of the Negro col* leges. The trust funds of the white institutions will still be larger, because of larger alumni donations, longer existence (in most cases), and past discriminatory allocation of state revenues. Also, because of the past disadvantage and deprivation of both Negro colleges and Negro college students, equality of educational opportunity will not be guaranteed merely by equalizing state appropriations. ${ }^{106}$ However, funds from the federal government ${ }^{107}$ and from private foundations ${ }^{118}$ may be used to fill the "discrimination gap." 100 Even though the comparisons

105. These groups have been called "the emerging hicrarchy of supra-tuiversity institutions." J. Perkins, The University IN TRANsition 66 (1966). See Millett, Statc Planning for Higher Education, 46 EDUCATIONAL RECORD 223 (1965), and Conant, Shapingt Educational Policy, 38 STATE Government 34 (1965). They have increasing ccitrallecd control over appropriations requests for higher education: it is much moic feasible to adjust expenditures among the various state institutions now than it would have bech ten years ago, Millett, $i d$. 230. Extensive judicial oversight would thercfore not be necessary to enforce this standard. When comparing per pupil expenditures of similar Negro and white institutions, the expertise of these agencies can also be utilized in determining how much is spent on graduate and professional programs at a white institution when stich programs do not exist at the Negro college. A weighting of the per pupil expenditure should be allowed in some cases. Although there will be some incvitable ovcrlap betwecn undergraduate and graduate programs (graduate students teaching undergraduates, undergraduates using graduate facilities, etc.), white institutions should be allowed to deduct certain expenditures (for research, for graduate instruction etc.) before thcy compute their per pupil expenditure if similar programs do not exist at the comparable Negro institution. For the role of the state planning agencics in long range fiscal planningf

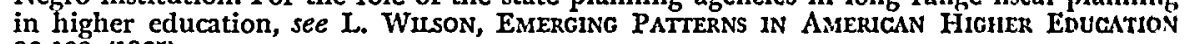
86-103 (1965).

106. Cf. Governor's Commission on the Los ANGeles Riots, VIOLENCE IN THE CirY-AN END OR A BEGINNING? 58 (1965): "The same educational program for children of uncqual backgrounds does not provide an equal opportunity for children to learn."

107. Federal aid to higher education has greatly increased in the last five years, and much more money is being provided for construction, teacher training, student scholarship aid, remedial programs, and library development; in the past, the grent bulk of federil aid went for research and for student loans. Henry, The Federal Government and Higher Education, 37 J. OF HIGHER ED. 187 (1966). See HEW, WHERE THE MONEx Is: ANNual Gude to OfFice of Education Procrams (1969) for a comprehensive list of federal programs.

108. From 1963 to 1967 , the Ford Foundation alone granted over $\$ 25,000,000$ to Southern Negro colleges. Strengthening Negro Colleges, 95 SGtool AND SocieTY 411 (1967). See also RIEsMan \& Jencks, supra note 55, at 453.

109. The proposed standard does not require "benign discrimination" to make up for past inequities. Such a requirement would be undefinable; if the state were requircl to "equalize" its Negro colleges at whatever cost, courts would be unable to determinc when this result had been achieved. A gradual realization of the judicial inability to
measure the intangibles involved in comparing separate educational systems was ant important cause of the abandonment of the separate-but-equal standard. See Scparate. but-Equal: $A$ Study of the Career of a Constitutional Concept, 1 RACE Rri. LAW REP. 283 (1956). Courts have, however, consistently upheld special remcdial programs to alleviate past discriminatory treatment in education. See Wanner v. County School Bd. of Arlington County, Virginia, 375 F.2d 452 (4th Cir. 1966). A state's voting special "catch-11)" 
of white and black institutions will be approximate ones and even though per pupil expenditure equalization will not completely meet the Negro colleges' fiscal needs, such a standard will at least provide Negro colleges far more state funds than they now receive and afford a more equitable distribution of the state's appropriations for higher education than now exists.

As Judge Wright stated in Hobson v. Hansen, 110 the "equal" half of the old Plessy v. Ferguson ${ }^{111}$ rule is still valid to the extent that it is a "reminder of the responsibility entrusted in the courts for ensuring that disadvantaged minorities receive equal treatment" in systems of public education once segregated by law and still segregated in fact.

\section{Fairness in Recruiting}

One of the methods by which the dual system is perpetuated in Southern higher education is checkerboard recruiting. Ascertainable and objective standards may be applied to the recruiting practices of state institutions of higher education, but so far courts have done little in this area. The concept of "discriminatory admissions practices" has usually been narrowly defined to mean the rejection of an otherwise qualified application on the grounds of race.112 However, in the plan submitted as part of the relief in the one case that has recognized an affirmative duty to integrate in higher education, ${ }^{113}$ specific recruiting practices were the primary means by which the state intended to extirpate the dual system. ${ }^{114}$ Recruiting is an especially important means of influencing attendance patterns at Southern colleges and universities because alumni of such institutions are almost entirely of one race.116 Yet a check of the field reports on Southern public colleges and universities compiled by HEW's Office of Civil Rights indicates that these

funds to its Negro colleges would seem to be constitutionally permissible, although only the North Carolina Legislature has done so. See Thorpe, One State's Program for Negro Colleges, 3 SoutherN ED. REP., Sept., 1967 at 29.

110. 269 F. Supp. 401, 496-97 (D.D.C. 1967), appeal dismissed, 393 U.S. 801 (1963).

111. 163 U.S. 537 (1896).

112. Meredith v. Fair, 298 F.2d 696, 701 (5th Cir.), cert. denicd, 371 U.S. 828 (1962).

113. Sanders v. Ellington, 288 F. Supp. 937 (M.D. Tenn. 1968).

114. Tennessee Departaient of Education, Plan for Achieving aleasisceul Desegregation of Public Colleges and Universities in Tennessee and for abolishisc a Dual SysteM of Higher Education 3 (Mar. 28, 1969) [hereinafter cited as SANders PLaN]. The Tennessee state colleges and universities were to have their recruiters visit all high schools within their area, make available all types of recruitment and admissions matcrial to minority group applicants, prepare special recruitment brochures to appeal to minority students, use interested black students and staff members in the recruiting effort, send complete information on financial aid to minority group students, set aside certain sums for financial aid to minority group students, and strengthen on-campus orientation, guidance, and counseling programs for black students. Id. at 3-4.

115. "Negroes are not likely to seek out colleges of which they have never heard, at which they are unsure of their reception," W. Younc, To BE Equal, 194 (1964). 
institutions tend to recruit almost exclusively at high schools of their own race.116

In the area of recruiting, courts should enforce the following stan. dards:

(1) Universities and colleges shall keep a record of recruiting visits; insofar as the high schools visited are identifiable by race, an equal amount of time will be spent at white and Negro high schools.

(2) In their admissions material and catalog, universities and colleges shall publicize the fact that they do not discriminate on the basis of race in admitting students and awarding financial aid.

(3) Universities and colleges shall maintain a biracial recruiting staff.

Compliance with these standards could be easily ascertained. A racially non-discriminatory recruiting effort will largely obviate the use of compensatory admissions standards for blacks at white institutions. Arguments for the latter policy ${ }^{117}$ ignore the fact that, despite the inferiority of many Southern predominantly black high schools, there are also several such high schools which are academically equivalent to the average white high schools and whose graduates are as academically qualified as white graduates. ${ }^{118}$ These black students are simply un. recruited, and the nonfeasance of white Southern colleges in this respect is dramatically emphasized by the success of Northern colleges in recruiting such students. ${ }^{119}$ By expanding the concept of admissions slightly, recruiting could be brought within the ambit of the case law requiring colleges to maintain nondiscriminatory admissions policies.

116. Examination of these records by the author at HEW's Office of Civil Rights, Mar. 18, 1969. At Louisiana State University, for example, the admissions and recruiting stalf are all white, recruiting visits are made only to white high schools, and nowhere in the LSU catalog is there mention of the fact that the University does not consider raco in admitting students or awarding financial aid: "There is very little contact with the Negro communty in Louisiana by representatives of LSU." HEW, Compliance Revlew Ficld Report under Title VI of the Civil Rights Act of 1964 for Institutions af Higher Education (OE Form 7003 9/67) dated Nov. 7, 1968, for Louisiana State University at 4 (filed in Office of Civil Rights of HEW).

117. Cf. Note, Integration of Higher Education in the South, 69 Colvar. L. REY. 112, 121 (1969), where it is asserted that "the absence of Negro students who can gain admission on a competitive basis" implies that "[i]f admissions standards are not lowercd, all institution (white) may remain totally segregated." Discussions on this subject frequently seem to assume that all Southern Negro high school graduates are inferior to white high school graduates and that all Southern white colleges and universities are Ivy Leaguo institutions. This is not true, of course. Many white high schools in the South are extremely inferior academically, and many public white colleges have admissions standards that are as low as many public Negro colleges. See generally K. ClaRk \& L. PLotKiN, TIIE Negro Student at InTEgrated Colleges 21 (1963).

118. Id. at 13. See also Dodd, The Progress of the Negro in Highor Educalian, 92 J. NEGRo ED. 485 (1963).

119. RIESMAN \& JENCKS, supra note 55 at 431. 
This inclusion would merely reflect the obvious fact that colleges and universities make affirmative efforts to interest high school students in applying for admission.

\section{Faculty Desegregation}

In elementary/secondary education, the Supreme Court has held that it is a denial of equal protection to assign teachers to schools on the basis of race if this practice is used in order to perpetuate the dual system. ${ }^{120}$ A lower court has stated: "[T]he presence of all Negro teachers in a school attended solely by Negro pupils in the past denotes that school a 'colored school' just as certainly as if the words were printed across its entrance in six-inch letters." 121 However, laissez-faire faculty hiring may be forbidden, and a race conscious allocation of teachers required ${ }^{122}$ as a specific mode of relief in the disestablishment of de jure segregation. ${ }^{123}$ Faculty desegregation has been asserted to be more important under desegregation plans involving freedom-of-choice than under those involving geographical zoning because of the necessity to present children exercising the choice with alternatives which are not identical with the two systems which existed under de jure segrega-

120. In Bradley v. School Bd., 382 U.S. 103 (1965), the Supreme Court held that it was improper for a court to approve a school desegregation plan without considering at a full evidentiary hearing the impact on this plan of faculty allocation on an allegedly racial basis. In Rogers v. Paul, 382 U.S. 198 (1965), the Court held that students in cegregated schools or in grades not yet desegregated had standing to challenge alleged racial assignment of faculty. It has been held that the allocation of faculty on a racial basis is unconstitutional per se-there is no need to prove an adverse effect on the quality of education; the only factual issue is whether or not race was a factor entering into the employment and placement of teachers. Wheeler v. Durham City Bd. of Educ., 363 Fad 738, 740 (4th Cir. 1966).

121. Brown v. County School Bd., 245 F. Supp. 549, 560 (WV.D. Va. 1965).

122. Bradley has been interpreted to forbid laissez-faire handling of faculty desegregation in certain cases:

[Bradley] implies that the accomplishment of that goal [student body integration] cannot be reached through the free choice of the teachers and that the Board must exercise its authority in making faculty assignments so as to assist in bringing to fruition the predicted benefits of school desegregation.

Monroe v. Bd. of Commr's, 380 F.2d 955, 960 (Gth Cir. 1967), rev'd on other grounds, 391 U.S. 450 (1968).

129. Dowell v. School Bd., 244 F. Supp. 971, 981 (W.D. OHla. 1965), aff'd, 375 F.2d 158 (10th Cir.), cert. denied, 387 U.S. 931 (1967). The court in Dowell also held that the admonition of the first Justice Harlan in his Plessy v. Ferguson dissent, 163 U.S. 537, 559 (1896) ("Our Constitution is color-blind,") should not be converted into "constitutional dogma barring affirmative action to accomplish the purposes of the Fourteenth Amend. ment. Thus, racial classifications which effect invidious discrimination are forbidden but may be upheld if deemed necessary to accomplish an overriding governmental purpose." Id. The HEW regulations, issued under Title VI of the 1964 Civil Rights Act, declare: "[R]ace ... may not be a factor in hiring or assignment ... except to correct the effects of past discriminatory assignments." 45 C.F.R. \$ 181.13 (1967). For a comprehensive description of how continued faculty segregation in the clementary/sccondinry schools of the South has been used to perpetuate pupil segregation, see U.S. Cosmassion ON CrviL. Rights, I Racial Isolation In the PUBlic Schools 67 (1967). 
tion:124 "It is essential that the ground rules of the plan be drawn with meticulous fairness .... [F]reedom-of-choice ... does not mean a choice between a clearly delineated 'Negro school' (including an all Negro faculty and staff) and a 'white school' (with all white faculty and staff)." 125

The necessity of a desegregated faculty and staff would seem to be equally important to the fair operation of what is essentially a "freedomof-choice system" in higher education. Yet there are greater difficulties in achieving desegregation here than in elementary/secondary education. Teachers are less fungible, and institutions are more autonomous. Also, teaching in colleges and universities is frequently combined with other activities (e.g., research or earning a graduate degree).

One case has held, however, that the state has a duty to desegregate its college faculties; ${ }^{126}$ for the same reasons as apply in elementary/ secondary education, this requirement should be incorporated into the state's affirmative duty in higher education. If there is complete faculty segregation which coincides with the historical racial composition of the college or university, it is clear that the state has been delinquent in its duty. The more difficult problem, however, is the degree of faculty desegregation courts will require. In elementary/secondary ed. ucation, two different solutions have been devised. In one series of cases, the percentage of black teachers in each school in the system has been required to approximate the percentage of black teachers in the entire system for a certain base year. ${ }^{127}$ In another series of cases, a specific percentage formula has been rejected, and a "substantial desegregation" goal has been set which includes the requirements that, when possible, teaching vacancies at schools of one race be filled

124. Cf. Kier v. County School Bd., 249 F. Supp. 239, 243 (W.D. Va. 1966):

[T]o be constitutionally acceptable, a freedom-of-choice plan will impose upon the school boards additional duties not required under a geographic plan. The ground rules must be laid in a way that will not discourage descgregation . . . . [ [ ] greater emphasis must be placed on faculty and staff desegregation in order to encotirige the pupil desegregation process.

125. Kier v. County School Bd., 249 F. Supp. 239, 246 (W.D. Va. 1966).

126. Lee v. Macon County Bd. of Educ., 267 F. Supp. 458 (M.D. Ala.), aff'd stub nom. Wallace v. United States, 389 U.S. 215 (1967). "There is no necessity for sctting out the facts in detail concerning the operation of these state colleges (Florence, Jacksonville, Livingston, Alabama State) since the evidence conclusively establishes... that these schools hatve been and continue to be operated as if Brown v. Board of Education were inapplicable in these areas." 267 F. Supp. at 474. The University of Alabama, Auburn University, tho University of Southern Alabama at Mobile, and Alabama College at Motevallo were not involved in this case, since they were governed by separate boards of trustees and were not directly administered by the Alabama State Board of Education, a defendant in the suit. 267 F. Supp. at 474 n.19.

127. Kier v. County School Bd., 249 F. Supp. 239, 247 (W.D. Va. 1966); Dowell v. Scliool Bd., 244 F. Supp. 971, 977-78 (W.D. Okla. 1965), aff'd, 375 F.2d 158 (10th Cir.), cert. denic'l, 387 U.S. 931 (1967). 
by teachers of the opposite race and that the School Board affirmatively encourage (by salary inducements, if necessary) transfer of teachers to schools of the opposite race. ${ }^{128}$

The latter system seems preferable for higher education. It avoids the rigidity and illusory clarity of the percentage formula (which may be manipulated through choice of the base year) and would allow gradual replacement of faculty and the preservation of academically superior departments at the various state colleges and universities. This solution was adopted in Lee v. Macon County Board of Education. ${ }^{123}$ Exact percentages were not specified, but the court directed the Alabama State Department of Education to recruit, hire, and assign teachers at state colleges and junior colleges under its direct control so as to accomplish some faculty desegregation by September, 1967.130

As long as a good faith start toward faculty desegregation is made, courts should allow a far longer time period for further faculty integration than is generally allowed in elementary/secondary education; this will enable colleges and universities to retain outstanding departments and to avoid the disruption which abrupt massive faculty transfers might induce. ${ }^{131}$ Since a significant amount of instruction at state universities is done by graduate students, the increasing integration of this part of the student body will result in a progressively more biracial teaching body. If two state institutions are geographically close to one another, a court might order courses available only at one college to be opened to students of the other college for credit. Alternatively, a court could order that teachers of one institution teach part time at the other institution. Where possible, either practice would create a greater degree of biracial instruction without extensive restructuring of the faculty of either school. This type of relief was actually ordered in the Sanders

128. Kelley v. Altheimer Pub. School Dist., 378 F.2d 483, 498.99 (8th Cir. 1967). If sufficient volunteers were not forthcoming, however, a "significant number" of Negro teachers were to be assigned to white schools the next year, and a "larger number" the year after that. An equitable distribution of the teachers with advanced degrees was also to be considered in making the transfers, 378 F.2d at 499.

129. 267 F. Supp. 458 (M.D. Ala.), aff'd sub nom. Wallace v. United States, 399 US. 215 (1967).

130. 267 F. Supp. at 484 .

131. The faculty situation differs from elementary/secondary education because in higher education it will often be impossible to transfer faculty without forcing them to move their homes; forcing such a move may result in the faculty Jeaving the state entirely. In elementary/secondary education, teachers an usually be assigned to a school of a different race without forcing the teachers to change their place of residence. Also, in higher education, there is usually a complex system of tenure and autonomous faculty-controlled hiring. For these reasons, desegregation which progresses by a gradual filling of vacancies as they occur and by financial inducements to teach at schools of an opposite race seems preferable to desegregation by an involuntary faculty transfer plan. 
case $^{132}$ where four state institutions ${ }^{133}$ were within a forty mile radius of the center of Nashville. ${ }^{134}$

\section{E. Construction and Expansion of Facilities}

In elementary/secondary school districts operating under freedomof-choice plans, site selection for new school construction is of critical importance because it is one of the ways in which former de jure segregation can be effectively perpetuated. ${ }^{135}$ As part of their affirmative duty to desegregate, elementary/secondary school officials must plan new construction to achieve the maximum possible integration; ${ }^{130}$ usually, this means locating new schools in areas which are not conspicuously monoracial. ${ }^{137}$ In higher education, traditionally, students have lived on campus, and so the location of the college has not significantly affected the racial composition of the student body. Such a model is becoming somewhat inaccurate, however, because of the spectacularly increasing number of commuter students; ${ }^{138}$ this development has made geographic considerations increasingly important in the location of new public institutions. In the South, therefore, although the racial demog-

132. 288 F. Supp. 937 (M.D. Tenn. 1968).

133. These institutions are the University of Tennessee Nashville Center, Tennessec A \& I State University, Austin Peay State University, and Middle Tennessec State University.

134. Cooperative academic programs were ordered to be initiated, with primary responsibility assigned to one institution for devising single programs to serve the entire four college area. SANDERS PLAN, supra note 114, at 7. The business administration faculty at Middle Tennessee State University and the University of Tennessec Nashvillo Center were to provide special courses at Tennessee A \& I, while Tennessec A \& I faculty members were to teach education, sociology, and Afro-American history courses at the two white institutions. The chief academic administrators of the three institutions were to arrange for joint appointments of selected faculty members and for the joint planning of other course offerings. Special incentives were required, in order to make the joint faculty appointments attractive. Incentives were to include payments for transportation costs, flexibility in home campus teaching schedules, and special salary bonuses. IIl. at 9. The two Nashville institutions, Tennessee A \& I and the University of Tennessec Nashivillo Center, were ordered to "undertake joint recruitment of faculty who will undlerstand from the beginning their cooperative responsibilities." Id. at 9. Finally, the two Nashville institutions were ordered to recognize complete transfer of course credits (assuming acceptable grades) so that a student's registration at one institution would allow him com. plete access to course offerings at the other institution. Id. at 9-10. To facilitate movement of students between the Nashville Center of the University of Tennessec and Tennessce A \& I, regular transportation service was to be provided, and course descriptions and schedules at both institutions were to be made available to students on both campuses. Ill.

135. Kelley v. Public School Dist. No. 22, 378 F.2d 483, 496 (8th Cir. 1967).

136. Wanner v. County School Bd., 357 F.2d 452, 454 (4th Cir. 1966).

137. United States v. Jefferson County Bd. of Educ., 372 F.2d 836 (1966), aff'd on rchear. ing with modifications, 380 F.2d 385, 394 (5th Cir.), cert. denied, 389 U.S. 810 (1967); United States v. Bd. of Pub. Instruction, 395 F.2d 66, 69-70 (5th Cir. 1967).

138. A commuter is a student who lives off campus; the term is often used to designate students who live at home. Colleges with a large number of such students may expand more rapidly than other colleges, since they do not have to construct as many additional dormitories. See generally L. WiLson, EMIERGING PATtERNS IN AMERICAN Higher Educhtion 46-71 (1965). 
raphy of the immediate neighborhood of the selected site (so important in elementary/secondary school construction) is not a factor in locating new institutions of higher education, placement of a new college or a new branch of a white university can have a profound impact on the perpetuation of the dual system if it is located within the commuter range (usually estimated to be a radius of about forty miles) ${ }^{139}$ of an existing public black college. The predictable effect of such action is to draw off the white commuter students who would otherwise be forced to attend the Negro college. ${ }^{140}$ In the border states, substantial "reverse integration" has been achieved in Negro colleges which happen to have been the only institution of public higher education within the commuter radius. ${ }^{141}$

If a new college or university is to be located close enough to an existing public Negro institution to attract a substantial number of its commuter students, the court should order the two public institutions consolidated under the same administration and any geographic separation justified functionally. In such a situation, the state would be required either to locate new construction on the black campus or "pair"142 the new institution and the Negro college in order to avoid duplication of courses and the creation of separate black and white campuses at the same nominal institution.

There is already precedent for such action. In Bradley $v$. Board of Public Instruction, ${ }^{143}$ the court ordered Gibbs Junior College (a black institution in St. Petersburg, Florida) and predominantly white St. Petersburg Junior College placed under the same administration; it was held that Gibbs should be gradually phased out of existence because a new branch of St. Petersburg Junior College was being constructed in

139. In the Sanders case, this was the radius used to determine which state institutions were to be included in cooperative planning for joint faculty appointments and course offerings. SANDERS PLAN, supra note 114 , at 4.

140. In the $A S T A$ case, the plaintiffs alleged this to be the state's motive in constructing a new branch of Auburn University in Montgomery, Alabama. When the previously private University of Houston was taken orer by the state of Texis, most of the white commuter students who had previously attended predominantly Negro Texas Southern University (also in Fouston) transferred to the University of Houston. RIEs:ras: \&. JENCRS, supra note 55, at 470.

141. In 1954, Lincoln University (Jefferson City, Mo.), Bluefield State Collcge (Bluefield, W. Va.), and West Virginia State College (Charleston, W. Va.) had student bodies which were entirely black; in 1967, their enrollments had become slightly more than half white chiefly because there was no other college nearby. See Allen, The Possibilities of Integration for Public Colleges Founded for Negroes, 35 J. NEcro ED. 452 (1966).

142. The term "pairing" refers to a desegregation plan sometimes used in clementary/ secondary education: a Negro and a white school are consolidated, and (for examplc) the buildings of one are used for grades 1-6 of the merged school, and the buildings of the other are used for grades 6-12 of the new school.

143. 10 RACE REL. L. REP. 117, Civ. no. 64-98 (M.D. Fla. decided March 15, 1965). 
Clearwater, ten miles away. The court found that both junior colleges had racially non-discriminatory admissions policies, but that Gibbs' facilities were inferior. The consolidation was ordered because if three junior colleges existed in the same commuter area, blacks would probably continue to attend Gibbs, and the two branches of St. Petersburg Junior College would probably be predominantly white.

If the new college or university is located outside the commuter range of an existing Negro institution, the chances are good that it can be integrated from the very beginning, but the court should require the state to show that it is adopting affirmative measures to ensure that the student body will be biracial. Because of the importance of the institution's initial "racial image" in influencing future student choice, a court might wish to attach more stringent conditions to the opening of the new school than it does to the operation of an existing institution. Though there would appear to be no theoretical difference between a new school and a school already in operation, in the elementary/ secondary education cases, courts have seemed willing to impose stricter conditions on new schools. ${ }^{144}$ This may represent a feeling that it is easier to intervene at the planning stage before faculty are hired and curricula are set. It may, however, be a recognition that the most important factor in the success of a freedom-of-choice plan is a strongly biracial student body. ${ }^{145}$ Since college and university enrollment is determined by free student choice, the importance of a new college's initial "racial image" would seem to be at least as great as in elemen. tary/secondary education, and the court might require that at certain percentage of the faculty at a new college be black or that special remedial courses be offered to attract black students. ${ }^{140}$

144. Montgomery Bd. of Educ. v. Carr, 400 F.2d 1, 9 (5th Cir. 1968), rev'd on othar grounds, 395 U.S. 225 (1969).

145. U.S. CoMmission ON GiviL. Rights, Southern Schoot. Desegregrtion 88 (1967),

146. There are precedents for this in the elementary/secondary education cases. In Montgomery Bd. of Educ. v. Carr, 289 F. Supp. 647 (M.D. Ala. 1968), Judge Johnson found that the newly constructed Jefferson Davis High School seemed destined to be all white. and he required it to have a fixed 5:1 white to Negro teacher ratio when it opened (If necessary the court insrtucted the Board to give an affirmative preference to black applicants). The Fifth Circuit, however, modified this decree to require only "approximately or substantially" this ratio, 400 F.2d 1, 9 (1968). The Supreme Court raversed the Fifth Circuit, however, and reinstated Judge Johnson's original order declaring that, in the light of Green, the "more specific and expeditious order of Judge Johnson" was to be enforced. United States v. Montgomery County Bd. of Educ., 395 U.S. 225, 237 (1969) In United States v. Jefferson County Bd. of Educ., 372 F.2d 886, 900 (1966), aff'd on rc* hearing with modifications, 380 F.2d 385 (5th Cir.), cert. denied, 389 U.S. 840 (1967), the Fifth Circuit ordered that remedial courses be provided at white schools in order to altrict black students under freedom-of-choice plans. 


\section{Conclusion}

Application of these standards will produce more total integration, upgrade the historically Negro colleges, and preserve the cultural/ psychological and remedial functions of these colleges. The rule that no student, black or white, may be denied entrance to any public college simply because of his race will continue to be strictly enforced. Since in higher education, the goal is not simply a "unitary non-racial system" but instead a system where there are a number of institutions serving diverse student needs, the state's duty is defined in terms of practices instead of results. Because the natural preferences of students may keep certain institutions somewhat more black (or white) than others, the simple Green test of achieved integration will not be conclusive as to whether a state is fulfilling its affirmative duty in higher education. The justification for requiring these practices is that they should eventually lead to enough integration at each institution to eliminate the stigma of racial inferiority attaching to the historically Negro colleges and the "colored need not apply" aura of the traditionally white colleges. The ultimate goal is a system of state institutions where academic superiority is not uniformly traceable to historic racial classification.

A broader duty than racially nondiscriminatory admissions policies should be imposed in public higher education because, sixteen years after Brown I, state colleges and universities in the South are still characterized by racial separation and a general inferiority of historically Negro institutions. In the past, when it became clear that the rights of black students were infringed, the federal courts began to enforce more rigid standards of "equality" in the pre-Brown higher education cases and of "desegregation" in the post-Brown elementary/secondary education cases. Once again, courts must become more actively involved in the struggle to secure the Fourteenth Amendment rights of black students in higher education: here also, the time for deliberate speed has run out. 